\title{
Protecting children's health against environmental exposure to heavy metals - theory versus practice
}

* Department of Environmental Health, School of Public Health in Bytom, Medical University of Silesia in Katowice (Poland),

* Department of Doctoral Studies, Department of Health Economics and Health Management, School of Public Health in Bytom, Medical University of Silesia in Katowice (Poland;

e-mail:kgut@sum.edu.pl

Keywords:

heavy metals, cadmium, lead, zinc, children's exposure, non-dietary exposure, sport field, Upper Silesia

\section{Abstract}

The high level of heavy metals is one of the main indicators of soil contamination, which is a significant risk to ecological and health safety. Lack of regulations requiring the examination of the level of contamination in the areas where recreational facilities for children are located directly translate into the lack of preventive or corrective actions and leads to the persistence of a permanent threat connected with a high level of heavy metals concentration in soils. The aim of the study was to identify significant sources of exposure of children to heavy metals depending on the location of recreational areas (sports fields). The results show a high concentration of cadmium, lead and zinc in the analysed soils. Of all samples, more than $70 \%$ of them have values exceeding the limit values of cadmium in soils. In the case of lead and zinc, the normative values were exceeded, respectively, in $44 \%$ and $64 \%$ of soil samples. Practical solutions introduced in the framework of regulations related to environmental protection do not correlate in practice with an extensive obligation to protect the health of children and adolescents, whose performance is clearly focused on medical problems, disregarding the risk resulting from environmental factors.

(c) IOŚ-PIB

\section{INTRODUCTION}

On the territory of Poland, the area that is polluted most by heavy metals is Upper Silesia. Research conducted in this area indicate clearly that heavy metals are identified as one of the most important current health risks [Dziubanek, Baranowska, Oleksiuk 2012; Nieć, Baranowska, Dziubanek et al. 2013; Nieć, Marchwińska-Wyrwał 2017].

Heavy metals are persistent contaminants; they do not undergo biological degradation, and they accumulate in all elements of the environment, especially in the soil. Depending on the form in which they occur, heavy metals that bind to DNA and nuclear proteins cause malfunctioning of cells and show diversified toxicity [Jaishankar, Tseten, Anbalagan, Mathew, Beeregowda 2014]. Lead and cadmium are distinguished amongst the most toxic elements, carcinogenic properties of cadmium were confirmed in 1993 by the International Agency for Research on Cancer [Tchounwou, Yedjou, Patlolla 2012].

The oral and inhalation routes have a main participation in exposure to heavy metals; however, among the group most vulnerable to these metals' action, which is constituted by children and youth, non-dietary sources are of the greatest significance. They are connected with heavy metals intake orally, however, not through food but by ingesting dust particles or impurities located on hands or toys that are put in the mouth [Nieć, Baranowska, Dziubanek et al. 2013, WHO 2005]. Considering the physiological conditions, as well as behaviours specific to young age during games and playing on playgrounds and playing fields, where often the phenomenon of secondary emission occurs, the population of children and youth is a group at special risk [EPA 2007].

Children and youth are protected in a special way, and the broad range of this protection is demonstrated in numerous legal regulations, concerning basically all areas of life. Both national and international legislation [Konwencja o Prawach Dziecka 1989; Europejska Karta Społeczna 1961, Ustawa o Rzeczniku Praw Dziecka 2000] place special emphasis on protecting the health of the 
youngest members of the society. Children's safety is to be ensured by appropriate legal regulations (standards), related to technical and organisational issues, as well as environmental conditions. While implementing various social tasks one of the principal tasks of public authorities, expressed in Art. 68 of the Constitution, is ensuring special healthcare to this group [Konstytucja Rzeczypospolitej Polskiej 1997].

It is usually indicated that the cause of many health problems of children and youth in Poland is the low quality, narrow scope and hindered accessibility to prophylactic and medical care and social assistance, and this situation is a demonstration of a lack of a coherent, consequent policy of the state towards children [Respond 2014]. At the same time, the significant impact of environmental pollution on health is omitted. As it appears from the report of the World Health Organization of 2016, the health condition of children under 5 years of age is determined to the greatest extent by environmental factors [Prüss-Ustün, Wolf, Corvalán, Bos, Neira 2016]. What also proves the importance of linking the environment's quality with the health condition is the fact of adopting, during the 56th session of the Sejm, changes in the state budget and allocating funds for creation of Zbigniew Religa Silesian Centre for Clinical and Scientific Prevention of Environmental, Civilizational, and Old Age Diseases (Śląski Ośrodek Kliniczno-Naukowego Zapobiegania i Leczenia Chorób Środowiskowych, Cywilizacyjnych i Wieku Podeszłego im. prof. Zbigniewa Religi) [Relacja z 56. posiedzenia Izby].

The aim of the National Health Programme for 2016-2020 is to impact the coherence of public authorities' actions, and its strategic goal is expanding life in good health, improvement of health and the related quality of life of the population and diminishing health-related social inequalities, whereas one of the operational goals is limiting the health risk resulting from physical, biological and chemical hazards in the external environment, including those in recreational places, such as sports fields and playgrounds [Rozporządzenie w sprawie Narodowego Programu Zdrowia... 2016].

\subsection{The aim of the study}

The aim of the study was to indicate significant sources of hazards to children's health related to heavy metals depending on the location of recreational areas (sports fields).

\section{MATERIAL AND METHODS}

The material for the research were samples of soil collected from the area of school sports fields $(n=30)$ and residential neighbourhood sports fields $(n=22)$ located in Chorzów - a city located in the central part of the Upper Silesian Industrial Region, where very intensive industrial activity had been conducted for many years (steelworks, nitrogen works, power plant). The school and sports fields from which samples were collected for analysis are located on land that is placed under the city's administration.

In order to ensure sample representativeness, each analysed sample consisted of a dozen or so sub-samples of the surface soil (layer from 0 to $20 \mathrm{~cm}$ ) with a total mass of $\pm 500 \mathrm{~g}$. The collected material was sieved (mesh size $<2 \mathrm{~mm}$ ) and dried to dry mass at $105^{\circ} \mathrm{C}$. The microwave mineralisation process was carried out in Magnum II reactors (Ertec), using spectrally clean nitric acid as the reagent. Using an INTEGRA XL spectrometer, the concentration of heavy metals (cadmium, lead and zinc) in the samples was quantified using the technique of inductively coupled plasma optical emission spectrometry (ICP-OES). The values determining the limit of quantification (LOQ) for each element were specified at the following levels: $\mathrm{Cd}$, $\mathrm{LOQ}=1 \mathrm{mg} / \mathrm{kg}$ dry weight (dry wt.); Pb, LOQ = $20 \mathrm{mg} / \mathrm{kg}$ dry wt.; Zn, LOQ = 12 mg/kg dry wt.

\section{RESULTS AND DISCUSSION}

The results obtained in the study show high concentration of heavy metals in the soils. The concentration range of each element was equal to: $<\mathrm{LOQ}-56.88 \mathrm{mg} / \mathrm{kg}$ dry wt. for cadmium, $27.57-2,724.80 \mathrm{mg} / \mathrm{kg}$ dry wt. for lead and $63.38-10,403.26 \mathrm{mg} / \mathrm{kg}$ dry wt. in the case of zinc, respectively (Table 1 ).

The estimated heavy metal concentrations were compared with the maximum permissible concentration (MPC), which the ordinance of the Minister of the Environment of 1st September 2016 on the method of evaluating the earth's surface contamination specifies at the level of: $2 \mathrm{mg} / \mathrm{kg}$ dry wt. for cadmium, $200 \mathrm{mg} / \mathrm{kg}$ dry wt. for lead and $500 \mathrm{mg} / \mathrm{kg}$ dry wt. for zinc [Rozporządzenie w sprawie sposobu prowadzenia oceny zanieczyszczenia powierzchni ziemi 2016]. The results obtained by analysing all the samples show that more than $70 \%$ of the values exceed the permissible values of cadmium in soils. In the case of lead and zinc, the values specified in the ordinance were exceeded in $44 \%$ and $64 \%$ of samples, respectively. In case of all samples, the highest mean concentrations were estimated in soils from school sports fields (Figures 1-3). The mean cadmium content ( $7.56 \pm 10.74 \mathrm{mg} / \mathrm{kg}$ dry wt.) quantified in samples collected from the school sports fields exceeded a few times the maximum permissible value.

The highest cadmium concentration in soil, which exceeded almost 30 times the value determined in the ordinance $(2,844 \%$ MPC) was estimated in sample collected from the sports field located at ul. Lwowska in Chorzów. As the study shows, the activity of children and youth whilst using recreational facilities, including sports fields, is connected with exposure to high concentrations of heavy metals and poses a significant hazard to their health. Despite this fact, amongst the regulations connected with the method of establishing, constructing and exploiting this type of facilities, there are no regulations that would directly order undertaking of specific actions, the aim of which would be 
Table 1. Concentration of $\mathrm{Cd}, \mathrm{Pb}$ and $\mathrm{Zn}$ in samples collected from the areas of school sports fields and residential neighbourhood sports fields in Chorzów [mg/kg dry wt.].

\begin{tabular}{|c|c|c|c|c|c|c|}
\hline \multirow{2}{*}{ Parameter } & \multicolumn{3}{|c|}{ School sports fields } & \multicolumn{3}{|c|}{ Residential neighbourhood sports fields } \\
\hline & Cd & $\mathbf{P b}$ & $\mathbf{Z n}$ & Cd & $\mathbf{P b}$ & $\mathbf{Z n}$ \\
\hline Median & 4.25 & 207.21 & 927.93 & 2.73 & 113.72 & 446.31 \\
\hline Minimum value & $<\mathrm{LOQ}$ & 27.57 & 104.51 & $<\mathrm{LOQ}$ & 30.11 & 63.38 \\
\hline Maximum value & 56.88 & $2,724.80$ & $10,403.26$ & 17.66 & 683.37 & $3,124.27$ \\
\hline $\begin{array}{l}\text { Maximum permissible } \\
\text { concentration (MPC) }\end{array}$ & 2 & 200 & 500 & 2 & 200 & 500 \\
\hline
\end{tabular}

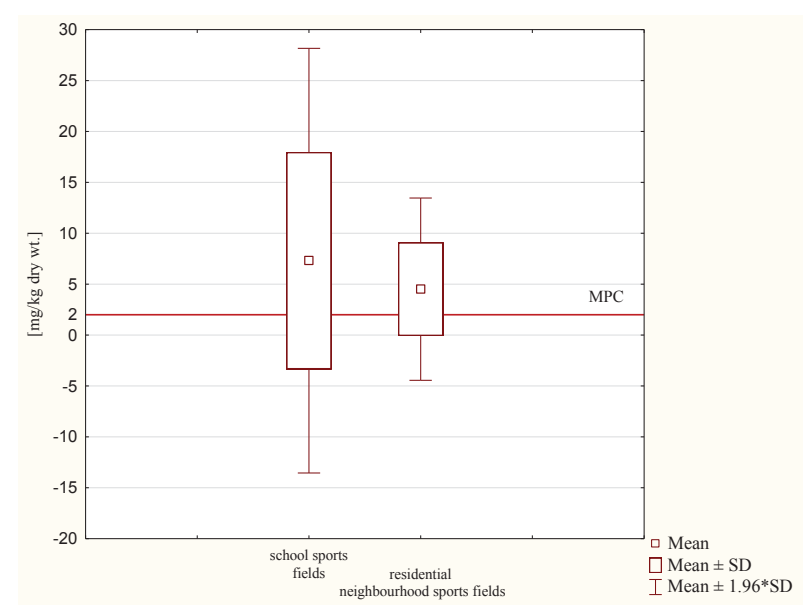

Figure 1. Cadmium content in samples of soils collected from the area of sports fields in Chorzów.

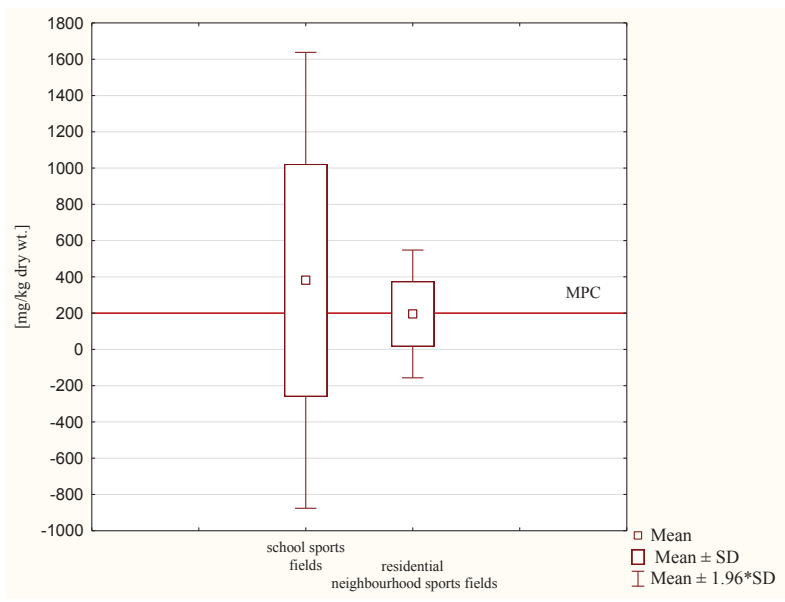

Figure 2. Lead content in samples of soils collected from the area of sports fields in Chorzów.

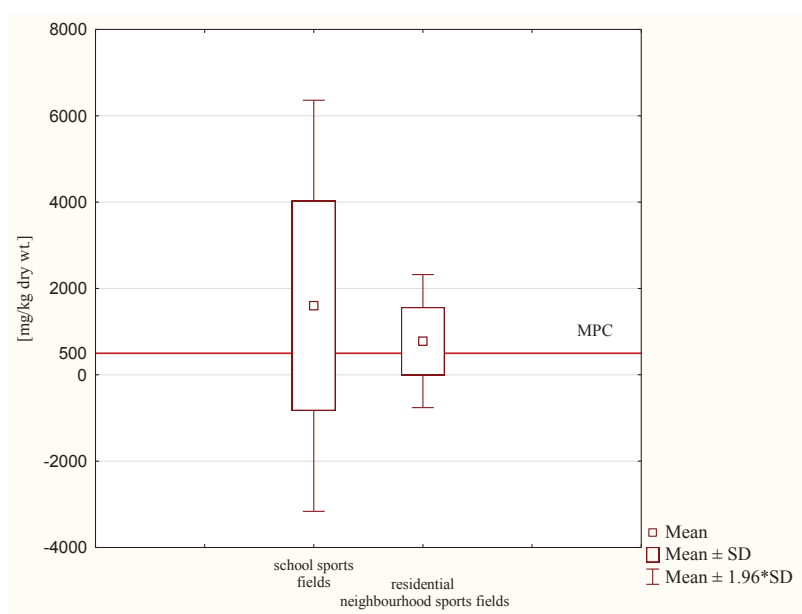

Figure 3. Zinc content in samples of soils collected from the area of sports fields in Chorzów.

identification of the environmental risk factors in the area of a planned or existing facility.

This does not mean, however, that there is absolutely no such type of regulations. The ordinance of the Minister of the Environment of 9th September 2002 on soil quality standards and earth quality standards (Journal of Laws No. 165, item 13590) [Rozporządzenie w sprawie standardów jakości gleby... 2002], currently superseded by the ordinance of the Minister of the Environment of 1st September 2016 on the method of evaluating earth surface contamination (Journal of Laws.2016.1395) [Rozporządzenie w sprawie sposobu prowadzenia oceny zanieczyszczenia... 2016], inter alia, deserve particular attention in this regard. Both the previously valid regulation and the provisions superseding it play an important role in shaping awareness connected with soil protection, amongst both national and local government administration authorities and the earth's surface owners. The explanatory statement of the new ordinance indicates that the Ordinance of 2002 gave the administration a 
tool for studying and evaluating the condition of the soil environment quality and made the earth's surface owners (particularly of industrial areas) aware of the responsibility for the environment's condition - although this conclusion seems to be too far reaching [Uzasadnienie do projektu Rozporządzenia Ministra Środowiska w sprawie sposobu prowadzenia oceny zanieczyszczenia].

Determination of the highest permissible concentrations for each element and compound, diversified depending on the method of land use, constitutes a clear reference point and specific guidelines when evaluating the contamination level.

At the same time, it should be pointed out that the Ordinance of 2016 regulating the method of analysing soil contamination does not impose an obligation of making such measurements. In accordance with the valid regulations, the evaluation of earth surface contamination is only performed in cases provided in the Act of the 27th April 2001 Environmental Protection Law (Journal of Laws.2017.519 uniform text) [Ustawa Prawo ochrony środowiska 2001]. Pursuant to the Act, the source of information about the environment is in particular the State Environmental Monitoring. The legislator's assumption was for the State Environmental Monitoring to support actions to the benefit of environmental protection [Ustawa Prawo ochrony środowiska 2001]. However, taking into account the adopted assumptions of the State Environmental Monitoring Programme for 2016-2020, which in relation to soil provides for analysis of its chemistry only in 216 selected fixed measurement and control points located on agricultural fields in the territory of the whole state
[Program Państwowego Monitoringu Środowiska na lata 2016 - 2020], it should be ascertained that its usefulness is low in controlling environmental hazards, both taking into account limitation of actions only to cultivable soils or collection of only few samples in contaminated areas, which does not show the actual condition of their contamination [Piekut, Baranowska, Marchwińska-Wyrwał, Ćwieląg-Drabek et al. 2018]. The surveillance of the sandbox pollution status carried out by the State Sanitary Inspection is also limited, as it is focused only on microbial contamination and does not include heavy metal contamination [Stan sanitarny kraju w roku 2016].

\section{SUMMARY}

The increased level of heavy metals is one of the main indicators of soil contamination, which constitutes a significant hazard to the health and ecological safety. The lack of regulations that would order examining the contamination level of the areas where recreational facilities for children and youth are located directly translates to a lack of preventive or remedial actions and leads to a situation in which constant threat connected with high heavy metal concentration in the soils exists. The solutions that are valid in practice, which are being introduced within the framework of regulations connected with environmental protection, do not correlate in practice with the wideranging obligation to protect the health of children and youth, the execution of which clearly focuses on medical problems, omitting the environmental risk factors.

\section{REFERENCES AND LEGAL ACTS}

DZIUBANEK G., BARANOWSKA R., OLEKSIUK K.: Metale ciężkie w glebach Górnego Śląska - problem przeszłości czy aktualne zagrożenie? JEcolHealth 2012; vol. 16, nr 4

JAISHANKAR M., TSETEN T., ANBALAGAN N., MATHEW B.B., BEEREGOWDA K.N.: Toxicity, mechanism and health effects of some heavy metals. Interdisciplinary Toxicology. 2014; Vol. 7(2): 60-72

NIEĆ J, BARANOWSKA R, DZIUBANEK G i wsp.: Narażenie środowiskowe dzieci na metale ciężkie zawarte w glebach z placów zabaw, boisk, piaskownic i terenów przedszkoli z obszaru Górnego Śląska. JEcolHealth, vol. 17, nr 2, kwiecień-czerwiec 2013

NIEĆ J., MARCHWIŃSKA-WYRWAt E.: Przegląd badań i działań Profilaktycznych związanych z narażeniem dzieci śląskich na metale ciężkie. Polski Przegląd Nauk o Zdrowiu 1 (50) 2017

PIEKUT A., BARANOWSKA R., MARCHWIŃSKA-WYRWAŁ E., ĆWIELAC-DRABEK $M$, et al.: Is the soil quality monitoring an effective tool in consumers' protection of agricultural crops from cadmium soil contamination?-a case of the Silesia region (Poland). Environ.Monit.Assess.2018; Vol.190, No.1, p.1-9, 25
PRÜSS-USTÜN A., WOLF J., CORVALÁN C., BOS R., NEIRA M.: Preventing disease through healthy environments: a global assessment of the burden of disease from environmental risks. Geneva:World Health Organization (WHO); 2016

RESPOND E.: Prawne aspekty ochrony zdrowia dzieci w Polsce. Roczniki Nauk Prawnych, t. XXIV, nr 3- 2014

TCHOUNWOU P, YEDJOU C, PATLOLLA A, et al. Heavy Metals Toxicity and the Environment. EXS. 2012 ; 101: 133-164.

Environmental Protection Agency (EPA): A Decade of Children's Environmental Health Research. Highlights from EPA's Science to Achieve Results Program. Summary Report. U.S. Environmental Protection Agency Office of Research and Development; EPA/600/S-07/038; December 2007.

Intergovernmental Forum on Chemical Safety (IFCS). Children and Chemical Safety Working Group: Chemical Safety and Children's Health. Protecting the world's children from harmful chemical exposures: a global guide to resources. WHO. October 2005. Dostępne na stronie: http://www.who.int/ifcs/champions/booklet_ web_en.pdf. [Data dostępu: 15.01.2018 r.]. 
Europejska Karta Społeczna sporządzona w Turynie dnia 18 października 1961 r. (Dz.U.1999.8.67 ze zm.)

Konstytucja Rzeczypospolitej Polskiej z dnia 2 kwietnia 1997 r. (Dz.U.1997.78.483)

Sejm uchwalił ustawę budżetową na 2018 r. „To najlepszy budżet jaki mogliśmy wypracować dla polskich rodzin". Relacja z 56. posiedzenia Izby. Dostępne na stronie: http://www.sejm.gov.pl/sejm8.nsf/komunikat.xsp?documentld=3DC04307BDDCFEB8C12582120060F74F [Data dostępu: 15.01.2018r.]

Konwencja o Prawach Dziecka przyjęta przez Zgromadzenie Ogólne Narodów Zjednoczonych dnia 20 listopada 1989 r. (Dz.U.1991.120.526 ze zm.)

Program Państwowego Monitoringu Środowiska na lata 2016 - 2020. Dostępne na stronie: http://www.gios.gov. pl/images/dokumenty/pms/pms/PPMS_2016-2020.pdf [Data dostępu: 14.01.2018r.]

Raport: Stan sanitarny kraju w roku 2016. Główny Inspektor Sanitarny. Dostępne na stronie: https://gis.gov.pl/ images/Stan_sanitarny_kraju_2016.pdf [Data dostępu: 24.02.2018 r.]
Rozporządzenie Ministra Środowiska z dnia 9 września 2002 r. w sprawie standardów jakości gleby oraz standardów jakości ziemi (Dz. U. Nr 165, poz. 1359)

Rozporządzenie Ministra Środowiska z dnia 1 września 2016 r. w sprawie sposobu prowadzenia oceny zanieczyszczenia powierzchni ziemi (Dz.U.2016.1395)

Rozporządzenie Rady Ministrów z dnia 4 sierpnia 2016 r. w sprawie Narodowego Programu Zdrowia na lata 2016-2020 (Dz.U.2016.1492)

Ustawa z dnia 6 stycznia 2000 o Rzeczniku Praw Dziecka (Dz.U.2017.922 t.j.)

Ustawa z dnia 27 kwietnia 2001 r. Prawo ochrony środowiska (Dz.U.2017.519 t.j.)

Uzasadnienie do projektu Rozporządzenia Ministra Środowiska z w sprawie sposobu prowadzenia oceny zanieczyszczenia powierzchni ziemi. Dostępne na stronie: https://www.teraz-srodowisko.pl/media/pdf/ aktualnosci/2227-Projekt-rozporzadzenia-ocenazanieczyszczen-gleb.pdf [Data dostępu: 12.01.2018r.] 